\title{
Closing the gap between nursing research and practice
}

The problem of implementing valid research results in nursing practice is well known. Despite an accumulating body of knowledge about the effectiveness of some nursing interventions, a gap often exists between what is known and what is practised.

Continuing professional education has been promoted as one way to bridge the gap between research and practice so that patients may benefit. ${ }^{12}$ Davis et al described continuing medical education as the longest educational phase in the career of a physician, and this probably applies to other health professionals also. ${ }^{3}$ The term "continuing professional education", however, often conjures up images of traditional lectures by "experts" in dark theatres. A more encompassing description might be "any and all ways by which (health professionals) learn and change after formal training is completed". 4

This editorial will summarise what is known about the effectiveness of continuing professional education/ behaviour change strategies, and make suggestions for choosing appropriate activities.

\section{Evaluation of behavioural change strategies}

Several systematic reviews of a broad range of interventions to improve health professional practice in general, ${ }^{25-7}$ and nursing practice specifically, ${ }^{8}$ have been conducted. Although most reviews reported some improvement in practice, the importance of the change was not always clear.

One systematic review has focused specifically on the effectiveness of continuing nursing education, ${ }^{8}$ and covered complex interventions as well as traditional activities such as lectures. The author concluded that overall, continuing education was effective in improving practice, although it was not possible to ascertain the importance of these changes from the published review.

Other reviews have focused on specific interventions such as audit and feedback, ${ }^{9}$ educational outreach visiting, ${ }^{10}$ and computerised decision support, ${ }^{11}$ or a specific targeted behaviour, for example, immunisation, ${ }^{12}$ or a particular practice setting (eg, primary care)..$^{13}$ A recent "overview" of systematic reviews concluded that passive dissemination of information alone (even information viewed as important) was insufficient to improve the practice of physicians, although it may increase knowledge or create awareness (table 1) ${ }^{14}$ Behaviour change strategies which have shown an impact on practice include, prompts on patient charts ${ }^{15}$ and workshops that include interaction among participants. ${ }^{16}$

A taxonomy of interventions to improve practice has been developed by the Cochrane Collaboration on Effective Professional Practice (CCEPP). ${ }^{14}$ This is an international group of people interested in preparing and maintaining systematic reviews of the effectiveness of interventions that influence professional practice. A complete description of CCEPP's scope and methods can be found in the Cochrane Library. ${ }^{17}$

\author{
Table 1 Interventions to promote behavioural change in health \\ professionals*

\begin{tabular}{|c|c|c|}
\hline $\begin{array}{l}\text { Consistently effective } \\
\text { strategies }\end{array}$ & $\begin{array}{l}\text { Strategies with mixed } \\
\text { effects }\end{array}$ & $\begin{array}{l}\text { Strategies having little or } \\
\text { no effect }\end{array}$ \\
\hline $\begin{array}{l}\text { Education outreach } \\
\text { visits (for prescribing) } \\
\text { Use of a trained } \\
\text { person who meets with } \\
\text { professionals in their } \\
\text { practice settings to } \\
\text { provide information with } \\
\text { the intent of improving } \\
\text { practice. }\end{array}$ & $\begin{array}{l}\text { Audit and feedback } \\
\text { Any written or verbal } \\
\text { summary of clinical } \\
\text { performance of health } \\
\text { care professional over a } \\
\text { specified period of time. } \\
\text { The summary may also } \\
\text { include } \\
\text { recommendation for } \\
\text { clinical action. }\end{array}$ & $\begin{array}{l}\text { Educational materials } \\
\text { Distribution of } \\
\text { published or printed } \\
\text { recommendations for } \\
\text { clinical care, including } \\
\text { clinical practice } \\
\text { guidelines, audiovisual } \\
\text { materials, and } \\
\text { electronic publications. }\end{array}$ \\
\hline $\begin{array}{l}\text { Reminders } \\
\text { Any intervention, } \\
\text { manual or computerised, } \\
\text { that prompts } \\
\text { professionals to perform } \\
\text { a clinical action. }\end{array}$ & $\begin{array}{l}\text { Local opinion leaders } \\
\text { Use of providers } \\
\text { nominated by their } \\
\text { colleagues as } \\
\text { "educationally } \\
\text { influential". }\end{array}$ & $\begin{array}{l}\text { Didactic educational } \\
\text { meetings } \\
\text { Lectures. }\end{array}$ \\
\hline $\begin{array}{l}\text { Multifaceted } \\
\text { interventions } \\
\text { A combination that } \\
\text { includes two or more of: } \\
\text { audit and feedback, } \\
\text { reminders, local } \\
\text { consensus processes, } \\
\text { patient mediated } \\
\text { interventions. }\end{array}$ & $\begin{array}{l}\text { Local consensus } \\
\text { process } \\
\text { Inclusion of } \\
\text { participating } \\
\text { professionals in } \\
\text { discussion to ensure } \\
\text { that they agreed that } \\
\text { the chosen clinical } \\
\text { problem was important } \\
\text { and the approach to } \\
\text { managing the problem } \\
\text { was appropriate. }\end{array}$ & \\
\hline $\begin{array}{l}\text { Interactive educational } \\
\text { meetings } \\
\text { Participation of } \\
\text { professionals in } \\
\text { workshops that include } \\
\text { discussion. }\end{array}$ & $\begin{array}{l}\text { Patient mediated } \\
\text { interventions } \\
\text { Any intervention } \\
\text { aimed at changing the } \\
\text { performance of } \\
\text { professionals where } \\
\text { specific information was } \\
\text { sought from, or given } \\
\text { to, patients. }\end{array}$ & \\
\hline
\end{tabular}

*Adapted from Bero L, Grilli R, Grimshaw JM, et al. ${ }^{14}$ Reproduced with permission.

\section{Getting research into practice}

Getting research into practice is not as simple as choosing an intervention and hoping for the best. Aside from the intervention itself, mediating factors include the characteristics of the patient and the practitioner and the desired behaviour change. ${ }^{18}{ }^{19}$ Getting practitioners to start doing something new, such as routinely asking patients if they smoke, may require a different strategy than that used to get practitioners to stop doing something they do frequently. Furthermore, administrative or financial policies may exist within organisations and settings that act as disincentives to improving the practice of individuals.

Interventions should ideally be tailored to an individual's stage of change, and should address administrative barriers where appropriate. ${ }^{20}$ For example, health professionals might already be aware of the need for cervical screening and may not require an educational intervention, but they may need a prompt on the patient's chart. If, however, practitioners lack information, awareness, or skills, then strategies such 
Table 2 Implementation strategies for different needs*

\begin{tabular}{llll}
\hline & $\begin{array}{l}\text { Improve } \\
\text { knowledge/ } \\
\text { attitudes }\end{array}$ & $\begin{array}{l}\text { Improve } \\
\text { skills }\end{array}$ & $\begin{array}{l}\text { Change } \\
\text { practice }\end{array}$ \\
\hline Implementation strategies & + & $?$ & + \\
Educational outreach visits & + & + & + \\
Rorkshops with interaction & + & $?$ & + \\
Social marketing & + & $?$ & + \\
Multifaceted approaches & + & $?$ & + \\
Opinion leaders & + & - & $+/-$ \\
Patient mediated strategies & $?$ & $?$ & $+/-$ \\
Audit and feedback & + & $?$ & - \\
Educational materials & + & - & - \\
Didactic conferences & + & $?$ & - \\
Local consensus process & + & & +-
\end{tabular}

*Adapted from Davis and Thomson. $.^{25}+=$ improvement based on evidence from randomised controlled trials; ? = evidence is unclear or unavailable; $-=$ no improvement based on evidence from randomised controlled trials.

as educational workshops that involve a high degree of interaction might be effective.

\section{Planning for improving practice}

As professionals, we need to develop systems of scrutinising our practice with a view to self improvement. An initial needs assessment can be accomplished using strategies such as self reflection, reading, and discussions with respected peers. However, two studies have shown less impact on performance if clinicians choose their own topics for further learning, and more impact if lower preference topics were studied..$^{21}{ }^{22}$ It may be that practitioners tend to choose topics in which they have the greatest interest and are already quite knowledgeable.

The next step is to choose a learning activity, and there may often be a discrepancy between the health professional's preference for a style of continuing education and what might be most effective in actually improving practice. Tassone and Speechley found that Canadian physiotherapists preferred short courses, ${ }^{23}$ while Covell et al reported that physicians preferred reading. ${ }^{24}$ Yet, poorly designed courses and reading alone may have little impact on practice.

Reading materials can be useful if they are evidence-based. Secondary sources such as this journal are ideal because they only present high quality research, and provide a commentary on each abstract by a clinician. The Cochrane Library is another important evidence-based source of information and should be available in medical and nursing libraries. ${ }^{17}$ Table 2 contains suggestions for matching the need for learning with different educational strategies. ${ }^{25}$ Although short "courses" are popular, practice is likely to improve if lectures are minimised and a high level of reflection and interaction is encouraged. ${ }^{16}$ Other sources of information about behavioural interventions can be found in the CCEPP. ${ }^{17}$

Completion of a formal or informal educational activity, although important, is likely to be insufficient on its own to improve practice. Changing behaviour is a complex process, and clinicians may revert back to usual practices unless the new behaviours are reinforced. ${ }^{20}$ Individual nurses should attempt to identify practical barriers to change, which need administrative/organisational support, and then attempt to influence existing managerial or quality improvement structures to address these barriers.

The gap between research and practice is not merely the consequence of nurses failing to keep up to date. ${ }^{26}$ Changing behaviour is complex, involves many systems, and is unlikely to be solved solely by educational strategies. ${ }^{27}$ Other efforts such as organisational supports and resources that encourage nurses to participate in research projects, ${ }^{28-30}$ to connect with larger networks, ${ }^{31}{ }^{32}$ and to gain experience with critical appraisal tools and journal clubs ${ }^{33}$ are important considerations and should not be overlooked.

Senior Research Fellow MARY ANN THOMSON, BHSc(PT), MHSc Health Services Research Unit

Department of Public Health

University of Aberdeen

Foresterhill, Aberdeen AB25 2ZD, UK

I wish to extend my thanks to Dr M Pierrynowski, Ms B Lendrum, Dr J Grimshaw, and Sister J Citrine for providing critical comments and to Mrs C Allen for assistance in preparing the manuscript.

1 Felch WC, Scanlon DM. Bridging the gap between research and practice: the role of continuing medical education. JAMA 1997;277:155-6.

2 Davis DA, Thomson MA, Oxman AD, et al. Changing physician performance: a systematic review of the effect of continuing medical education strategies. JAMA 1995;274:700-5.

3 Davis DA, Thomson MA, Oxman AD, et al. Evidence for the effectiveness of CME. A review of 50 randomized controlled trials. JAMA 1992;268: CME. A

4 Davis DA, Fox RD, eds. The physician as learner: linking research to practice. Chicago: American Medical Association, 1994.

5 Beaudry JS. The effectiveness of continuing medical education: a quantitative synthesis. Journal of Continuing Education in the Health Professions $1989 ; 9: 285-307$

6 Grimshaw JM, Russell IT. Effect of clinical guidelines on medical practice: a systematic review of rigorous evaluations. Lancet 1993;342:1317-22. 7 Oxman AD, Thomson MA, Davis DA, Haynes RB. No magic bullets: a systematic review of 102 trials of interventions to help health care professionals deliver services more effectively or efficiently. Can Med Assoc 1995;153:1423-31

8 Waddell DL. The effects of continuing education on nursing practice: a meta-analysis. J Contin Educ Nurs 1991;22:113-8.

9 Mugford M, Banfield P, O'Hanlon M. Effects of feedback of information on clinical practice: a review. BMJ 1991;303:398-402.

10 Thomson MA, Oxman AD, Haynes RB, et al. Educational outreach visits to improve health professional practice and health care outcomes. In: The Cochrane Library [datab

11 Johnston ME, Langton KB, Haynes RB, et al. Effects of computer-based clinical decision support systems on clinician performance and patient outcome: a critical appraisal of research. Ann Intern Med 1994;120:135-42.

12 Gyorkos TW, Tannenbaum TN, Abrahamowicz M, et al. Evaluation of the effectiveness of immunization delivery methods. Can J Public Health 1994;85 (suppl 1): S14-30.

13 Soumerai SB, McLaughlin TJ, Avorn J. Improving drug prescribing in primary care: a critical analysis of the experimental literature. Milbank $Q$ 1989;67:268-317

14 Bero L, Grilli R, Grimshaw JM, et al. Closing the gap between research and practice. An overview of systematic reviews of interventions to promote implementation of research findings by health care professionals. $B M$, in press.

15 McPhee SJ, Bird JA, Jenkins CNG, et al. Promoting cancer screening. A randomized, controlled trial of three interventions. Arch Intern Med 1989; 149:1866-72.

16 Thomson MA, Oxman AD, Haynes RB, et al. Educational meetings, workshops and traineeships to improve health professional practice. In: The
Cochrane Library [database on CD-ROM and online], issue 4. Oxford: Cochrane Library data
Update Software, 1997.

17 Bero L, Grilli R, Grimshaw JM, et al, eds. Cochrane collaboration on effective professional practice module of the Cochrane database of systematic reviews. In: The Cochrane Library [database on CD-ROM and online], issue 4. Oxford: Update Software, 1997

18 Lomas J, Haynes RB. A taxonomy and critical review of tested strategies for the application of clinical practice recommendations: from "official" to "individual" clinical policy. Am J Prev Med 1987;4:77-94.

19 Cervaro RM. Continuing professional education and behavioural change: a model for research and evaluation. J Contin Educ Nurs 1985;16:85-8.

20 Prochaska JO, DiClemente CC, Norcross JC. In search of how people change. Applications to addictive behaviors. Am Psychol 1992;47:1102-14.

21 Sibley JC, Sackett DL, Neufeld V, et al. A randomized trial of continuing medical education. $N$ Engl J Med 1982;306:511-5.

22 Palmer RH, Louis TA, Hsu LN, et al. A randomized trial of quality assurance in sixteen ambulatory care practices. Med Care 1985;23:751-70.

23 Tassone MR, Speechley M. Geographical challenges for physical therapy continuing education: preferences and influences. Physical Therapy 1997;77:285-95.

24 Covell DG, Uman GC, Manning PR. Information needs in practice: are they being met? Ann Intern Med 1985; 103:596-9.

25 Davis DA. Thomson MA. Continuing medical education as a means of lifelong learning. In: Silagy C, Haines A, eds. A guide to evidence-based health care. London: BMJ Publishing Group, in press.

26 Tornquist EM, Funk SG, Champagne MT. Research utilization: reconnecting research and practice. AACN Clin Issues 1995;6:105-9.

27 Meah S, Luker KA, Cullum NA. An exploration of midwives' attitudes to research and perceived barriers to research utilisation. Midwifery 1996;12: 73-84.

28 Ashcroft T, Kristjanson LJ. Research utilization in maternal-child nursing: application of the CURN. Can J Nurs Adm 1994;7:90-102.

29 Kitson A, Ahmed LB, Harvey G, et al. From research to practice: one organizational model for promoting research-based practice. J Adv Nurs 1996;23:430-40.

30 Rodgers S. An exploratory study of research utilization by nurses in general medical and surgical wards. J Adv Nurs 1994;20:904-11.

31 Leighton-Beck L. Networking: putting research at the heart of professional practice Br J Nurs 1997:6:190-2.

32 Kettles AM. Grampian mental health divisional research unit. Nurs Stand 1997:11:33-4.

33 Kirchhoff KT, Beck SL. Using the journal club as a component of the research utilization process. Heart Lung 1995;24:246-50. 